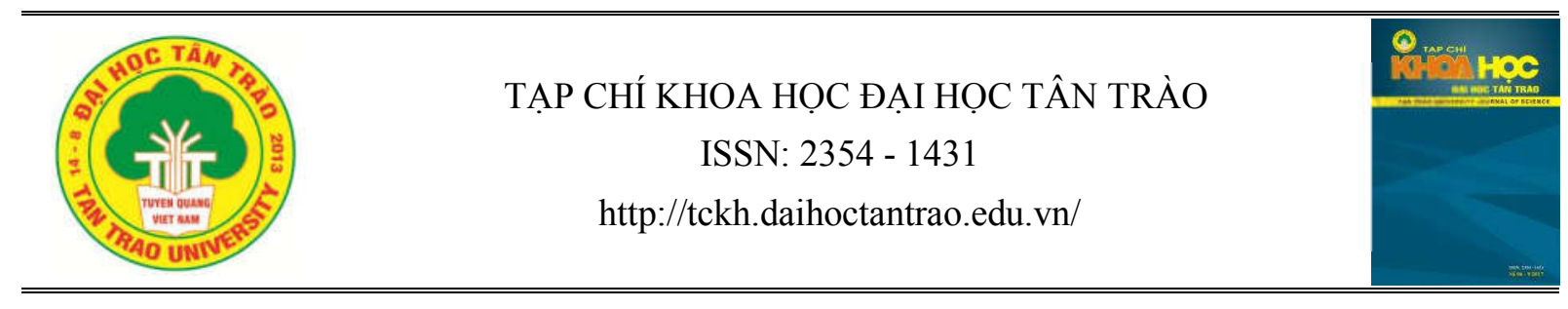

\title{
Hoàng Hoa Thám và những truyện kể dân gian
}

\author{
Triệu Thị Linh ${ }^{a}$ \\ ${ }^{a}$ Truò̀ng Đại học Tân Trào \\ *Email: trieulinhtq@gmail.com
}

\section{Thông tin bài viết}

Ngày nhận bài:

06/03/2018

Ngày duyệt đăng:

$12 / 6 / 2018$

Tù khoá:

Hoàng Hoa Thám, truyện kể dân gian.

\section{Tóm tắt}

Hoàng Hoa Thám là một nhân vật lịch sử xuất hiện trong giai đoạn dân tộc Việt Nam đối đầu với thực dân Pháp khi thời kỳ bình định quân sự sắp đi vào kết thúc. Đây là một hiện tượng đặc biệt, bởi Hoàng Hoa Thám đã lập tức là mối quan tâm chung của cả hai phía đối lập nhau về quyền lợi dân tộc; Những quan tâm đó được thể hiện thành các ghi chép, thành những thông tin truyền khẩu suốt từ thời điểm ông tại thế và kéo dài cho đến ngày nay, ở cả ba phạm vi: lịch sử, folklore và văn chương. Trong bài viết, chúng tôi đã lựa chọn vấn đề Hoàng Hoa Thám và những truyện kể dân gian để tìm hiểu nội dung : hình ảnh vị thủ lĩnh được lưu truyền và phản ánh trong những truyền ngôn của hai phía Pháp và Việt. Những cách thức và phương thức nghệ thuật mà tác giả dân gian sử dụng cũng như câu chuyện về tinh thần dân tộc được chúng tôi bàn đến trong quá trình phân tích những truyện kể dân gian về Đề Thám.
Hoàng Hoa Thám là một nhân vật lịch sử xuất hiện trong giai đoạn dân tộc Việt Nam đối đầu với thực dân Pháp khi thời kỳ bình định quân sự sắp đi vào kết thúc. Đây là một hiện tượng đặc biệt, bởi Hoàng Hoa Thám đã lập tức là mối quan tâm chung của cả hai phía đối lập nhau về quyền lợi dân tộc; Những quan tâm đó được thể hiện thành các ghi chép, thành những thông tin truyền khẩu suốt từ thời điểm ông tại thế và kéo dài cho đến ngày nay, ở cả ba phạm vi: lịch sử, folklore và văn chương. Trong giới hạn một bài viết, chúng tôi xin được đặt vấn đề Hoàng Hoa Thám và nhũng truyện kể dân gian, qua đó tìm hiểu hình ảnh vị thủ lĩnh được lưu truyền và phản ánh ra sao trong những truyền ngôn của hai phía Pháp và Việt ? Các tác giả dân gian đã sử dụng những phương thức nghệ thuật nào, như thế nào? Câu chuyện về tinh thần dân tộc sẽ được bàn đến trong quá trình chúng tôi phân tích, trả lời các câu hỏi trên.

Theo phân loại văn học dân gian, những truyện kể về Hoàng Hoa Thám liên quan đến hai thể loại là truyền thuyết và giai thoại. Cho đến hiện tại, trong nghiên cứu folklore có nhiều định nghĩa về hai thể loại này. Về truyền thuyết, chúng tôi chọn cách xác lập khái niệm của Kiều Thu Hoạch: "Truyền thuyết là một thể loại truyện kể truyền miệng, nằm trong loại hình tụ sụ dân gian, nội dung cốt truyện của nó kể lại truyện tích của nhân vật lịch sủ hoặc giải thích nguồn gốc các phong vật địa phuong theo quan điểm của nhân dân, biện pháp nghệ thuật phổ biến của nó là khoa truơng, phóng đại, đồng thời nó cũng sủ dụng các yếu tố hu ảo, thần kỳ nhu cổ tích và thần thoại; nó khác cổ tích ở chỗ không nhằm phản ánh xung đột gia đình, sinh hoạt xã hộ và số phận cá nhân mà thường phản ánh nhũng vấn đề thuộc phạm vi quốc gia dân tộc rộng lón; nó khác thần thoại ở chố nhào nặn tụ nhiên và xã hội trên co sở sụ thật lịch sủ cu thể chư không phải hoàn toàn trong trí twởng tuợng và bằng trí tương tuợng" [dẫn theo 10 , tr.72]. Cách hiểu này vừa bao quát được các

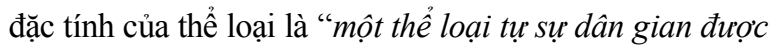
xây dựng tù̀ niềm tin và cảm hưng về nhũng giá trị thiêng liêng của cộng đồng, dân tộc" [1, tr.269] lại vừa có những phân biệt với các thể loại khác. Còn giai thoại, chúng tôi theo định nghĩa sau: "là một thể loại truyện kể ngắn gọn về một tình tiết có thực hoặc được thêu dệt 
của những nhân vật được nhiều người biết đến" [3, tr.112]. Tuy nhiên, trên thực tế, trong truyện kể dân gian nói chung và các văn bản kể chuyện của dân gian về Hoàng Hoa Thám nói riêng, ranh giới giữa hai thể loại này không phải lúc nào cũng rạch ròi ${ }^{1}$. Thậm chí, ở một số văn bản còn có những tình tiết hoặc yếu tố thần kì mang màu sắc của thần thoại. Vì thế, chúng tôi gọi chung những câu chuyện kể về Đề Thám sắp được phân tích dưới đây là truyện kể dân gian - một khái niệm bao trùm cả truyền thuyết và giai thoại nhưng lại không mang trọn vẹn đặc thù của từng thể loại đó. Thống kê trên các ấn phẩm và bản điện tử sưu tầm truyện kể dân gian về Hoàng Hoa Thám, chúng tôi có con số 64 truyện, trong đó nhiều nhất là các bản kể liên quan đến cái chết của Hoàng Hoa Thám - 35 truyện. Về nội dung, những chuyện kể này thường không hoàn chỉnh: kể về một quãng đời nào đó hoặc một phẩm chất nào đó của vị thủ lĩnh, hoặc cũng có lúc thiếu vắng những diễn biến lớp lang, hoặc không đầu không cuối... Về hình thức, chúng có thể sử dụng các motif thường gặp trong truyền thuyết là " $r a$ đời ki lạ, chiến công phi thuoòng và hóa thân (cái chêt thần ki)" [1, tr.111] theo hướng thiêng hoá khi miêu tả nhân vật lịch sử nhưng cũng có thể kết hợp với các chi tiết mang tính hiện thực theo lối kể của giai thoại.

Ở phương diện đầu tiên (sử dụng các motif thường gặp và miêu tả nhân vật theo hướng thiêng hóa), nguồn gốc xuất thân hay gốc tích của Hoàng Hoa Thám được các tác giả dân gian nhìn dưới góc độ hiện thực, vì vậy đây chủ yếu là các giai thoại. Chúng tôi thống kê có khoảng trên 10 mẩu truyện như vậy. Theo những gì Bouchet đã ghi lại từ dân gian thì: cha của Thám là Phó Quát, làm nghề thợ thêu, rất nghèo, đến làm thuê cho Cai Tổng Nghi và làm quen với người con gái trong làng vì xấu quá mà chưa có chồng. Họ sinh được người con trai gọi là Giai Thiêm. Sau đó, mẹ Thiêm bị cọp bắt, cha bị chết ở nhà lao Bắc Ninh. Thiêm mồ côi cha mẹ phải sống vất vưởng, làm thuê, chăn trâu... [7, tr.30].

Trong Chân twoóng quân, Phan Bội Châu kể rằng đã nghe từ các cụ già kể về Quan Hoàng, "mới sinh ra đã bị mất cha, không biết cha là ai, mẹ thì nghèo khổ, lưu lạc tới nơi đây, (...) làm con nuôi họ Hoàng do đó lấy họ là Hoàng. Sáu tuổi mẹ chết, cha nuôi cũng chết, bơ

\footnotetext{
${ }^{1}$ Và tình huống này cũng là phân vân của Nguyễn Thị Tâm khi sử dụng khái niệm truyền thuyết trong khóa luận của mình. Tác giả khoá luận nhận xét rằng một số truyện kể dân gian chưa đủ quy mô để xếp vào thể loại truyền thuyết vì nó chỉ có những motif, những vấn đề của thể loại truyền thuyết mà thôi [7, tr.29].
}

vơ côi cút, đi ở chăn trâu, nhà nghèo không có khả năng đi học" [2, tr.150]. Ngô Tất Tố và L.T.S trong Lịch sủ quân Đề-Thám Yên-Thế cũng cho biết: Thám vốn họ Trương. Ông Thân của Thám là một người làm ruộng rất nghèo ở vùng Yên Thế, mẹ là gì thì chưa rõ. Vợ chồng hiếm hoi chỉ có một người con gái, đến ngoài bốn mươi tuổi mới sinh ra Thám [9, tr.5]. Trong cuốn Bắc Giang địa chí, Trịnh Như Tấu chép lại theo lời kể người xưa, cũng có chi tiết khá tương đồng: cha của Thám làm ruộng ở làng Trũng, mất sớm, còn mẹ bị hùm bắt. Lúc nhỏ Thám phải đi ở nhờ nhà Bá Phức...[7, tr.30].

Bài viết của Hoài Nam lập luận về gốc tích lịch sử của "ông Đề Thám” cũng chủ yếu dựa vào truyền miệng, có nêu: Cha của ông Đề Thám là Trương Văn Thận, ông Thận học giỏi nhưng không thi đậu, làm nghề dạy học. Mẹ của ông Thám tên là Lương Thị Minh, rất khỏe và giỏi võ nghệ. Họ sinh được người con trai đặt tên là Nghĩa. Hai vợ chồng bị bọn hào lí địa phương tố giác nên đều bị bắt. Người vợ chống cự liền bị giết tại chỗ, người chồng bị đóng cũi giải về Kinh nhưng trên đường đi cắn lưỡi tự vẫn. Khi đó, người em là Trương Văn Thân bế cháu đi chơi, khi thấy động liền bế cháu đi trốn, thằng bé Nghĩa cải tên là Thiên [8, tr.76-77]. Theo thuyết này, xuất thân của Đề Thám có khác những thuyết trên, đó là được sinh ra từ gia đình thượng võ, có giáo dục, tuy nhiên số phận cậu bé Nghĩa lại tương đồng với những thuyết khác: cha mẹ mất sớm, phải lưu lạc từ nhỏ.

Có thể thấy rõ rằng, motif sụ ra đời ki lạ hoàn toàn không được sử dụng trong truyện kể về nguồn gốc xuất thân của Đề Thám. Điểm chung trong câu chuyện của các tác giả dân gian là vị thủ lĩnh này có xuất thân bình thưòng, thậm chí nghèo khổ, bất hạnh chứ không theo kiểu "là kết quả của sự hòa hợp giữa người với các hiện tượng tự nhiên”, hay kiểu “đời sống tự nhiên ùa vào làm kết tinh này nở người anh hùng" [1, tr.113] như motif ra đời kì lạ của Thánh Gióng (bà mẹ dẫm dấu chân ông Khổng Lồ), bà Chúa Bầu - một nữ tướng của Hai bà Trưng (được sinh ra từ quả bầu), v.v.. Và cũng dễ nhận ra, những truyền ngôn trong dân gian về nguồn gốc xuất thân của vị thủ lĩnh đã trở thành chất liệu/căn cứ chính cho/trong nhiều ghi chép sử và sáng tác văn chương. Vì vậy, những truyện kể này không chỉ là minh chứng cho sự quan tâm của dân gian đối với quá khứ của người anh hùng, mà nó còn 
thực hiện nhiệm vụ làm rõ, làm đầy, cung cấp và kết nối các thông tin đứt đoạn, khuyết thiếu về Đề Thám trong sử liệu.

Tiếp nối những mẩu chuyện về gốc tích ông Đề là các truyện kể về những phẩm chất đặc biệt và chiến công phi thuờng của ông. Ở mảng đề tài này, số lượng truyện dày dặn hơn cả, có hàng trăm câu chuyện kể, tập trung ở quãng thời gian Đề Thám còn nhỏ và khi làm thủ lĩnh nghĩa quân ${ }^{2}$. Trong những truyện kể này, các tác giả dân gian vừa sử dụng lối cường điệu, phóng đại vừa sử dụng trí tưởng tượng khi miêu tả sự phù trợ của vật thiêng, phép lạ dành cho người anh hùng.

Theo nhiều truyện kể dân gian, ngay từ nhỏ, Đề Thám đã bộ lộ những phẩm chất đặc biệt và là một hình ảnh toàn thiện: một mình cậu có thể đủ sức can ngăn hai con trâu đực húc nhau, thường rủ bạn đi bẫy hổ về nuôi, một mình có thể địch với mười đứa trẻ cùng lứa tuổi,...[7, tr.31]. Thắm ham mê đẽo gọt báng súng và trò chơi đánh trận giả, thường rủ đám trẻ chăn trâu làng Trũng, làng Chè, làng $A m, \ldots$ chơi cùng nhau. Thắm vừa có khả năng bài binh bố trận vừa thông minh, mưu trí, khi thì bày cách cho bọn trẻ giã ớt trộn vào cát cho vào ống nứa [7, tr.35], khi thì biết dùng tổ ong, tổ kiến, sử dụng mỏm đá, cây rừng [12, tr.7]... làm vũ khí chiến đấu. Không chỉ thế, Thắm còn là cậu bé giàu tình nghĩa, hay giúp đỡ bênh vực kẻ yếu, tính tính khảng khái, rộng lượng, đánh bắt được con gì hay trộm được gà vịt của nhà giàu Thắm đều rủ đám trẻ chăn trâu cùng lên rừng nướng ăn. Tuy là đứa trẻ ngụ cư, đi làm thuê nhưng cậu bé Thắm vẫn được lũ trẻ trong làng và các làng xung quanh yêu mến, kính nể và tôn là "Vua mục đồng" [7, tr.31].

Khi trở thành thủ lĩnh nghĩa quân, những phẩm chất đặc biệt của cậu bé Thắm, nay là Đề Thám càng được dân gian tô đậm. Những truyện kể về cuộc chạm chán giữa Đề Thám và phó đội Liên (tay sai của thực dân Pháp) đã cho biết thêm vị thủ lĩnh là một người bản lĩnh, dứt khoát, có tài bắn súng giỏi, chỉ bằng một phát bắn từ góc khuất trong lùm cây đã có thể giết chết phó đội Liên đang cưỡi ngựa di chuyển trên đường; hay chuyện giữa Đề Thám và Bút-sê (viên

\footnotetext{
${ }^{2}$ Hầu hết truyện đã được sưu tầm và ghi chép lại, một số được biên soạn thành sách/truyện phục vụ cho thiếu nhi.
}

quan Pháp ở Nhã Nam) thì ca ngợi Đề Thám còn có khả năng ứng đối linh hoạt, đanh thép với kẻ thù bằng thơ $[8$, tr.586-588]. Dân gian cũng lưu truyền câu chuyện ông dùng mưu trí cho nghĩa quân bí mật bỏ độc vào rượu để phá âm mưu ăn cướp của giặc Cờ đen [7, tr.35], hay hàng chục truyền ngôn kì thú về việc ông dùng chiến thuật "gậy ông đập lưng ông", "giả chết" để đối phó với âm mưu ám sát thủ lĩnh của cha nuôi Bá Phức và Lê Hoan [8, tr.300]. Giống như trong vè lịch sử, truyện kể cũng có đầy rẫy những mẩu chuyện nói lên tình cảm khăng khít giữa thủ lĩnh và dân làng. Họ truyền rằng: đến ngày làm mùa, cụ Hoàng đi thăm hỏi đám thợ từng làng. Gặp già hỏi già, gặp trẻ hỏi trẻ. Những đứa trẻ con của nghĩa quân quanh đồn, đối với cụ Hoàng đều như con cháu trong nhà. Lên làm giúp cụ Hoàng, bà con ngày làm đêm nghỉ, quây quần làm hàng xáo, hát ví, hát đúm đến sang canh, ăn uống thoải mái... Với bà con lân cận thiếu trâu bò, cụ Hoàng cho mượn, thiếu thóc gạo, cụ Hoàng cho vay, bao giờ có thì trả. Cụ Hoàng lại mượn thợ dựng đình lập chùa làm cả nhà thờ đạo cho dân bốn tổng [8, tr.374]. Tác giả Nguyễn Đình Bưu còn ghi chép được từ dân gian thuyết rằng: Cụ Hoàng còn tổ chức các hội chay tưởng niệm các thủ lĩnh nghĩa quân và các vong hồn tử sĩ. Ngày mười hai tháng Giêng hàng năm, đồn Phồn Xương tưng bừng trong những ngày hội thi làm cỗ, làm các loại bánh, thi đấu vật, thi võ, thi bắn,...Người khắp nơi về dự hội rất đông, không kể thành phần dân tộc. Cụ Hoàng còn cho đón cả gánh hát tuồng, hát chèo miền xuôi về dự hội. Cụ thích xem tuồng, diễn tích những anh hùng, những người yêu nước, yêu chính nghĩa. Tương truyền cụ Hoàng khi xem đến cảnh Hồ Xanh đánh mộc trong vở Hồ Xanh, Bảo Nghĩa thì rất vui thích, sẵn tráp tiền bên cạnh đổ thưởng tất cả [8, tr.375].

Có thể nói, trong con mắt và niềm tin của dân gian, những phẩm chất đặc biệt và sức mạnh phi thường tự thân của Đề Thám (như có sức vóc hơn người, có bản lĩnh, mưu trí, tài năng quân sự, hiệp nghĩa, gắn bó và hết lòng vì nhân dân, chiến đấu bảo vệ lẽ phải,...) đã có trong người anh hùng ngay từ khi còn nhỏ, được nuôi dưỡng và phát huy mạnh mẽ khi ông trở thành thủ lĩnh nghĩa quân. Ở đây, thủ lĩnh Đề Thám được hiện lên qua lăng kính cảm xúc của người kể chuyện theo hướng lựa chọn điều thiêng liêng, điều tốt đẹp và 
gắn với những vấn đề liên quan đến cộng đồng một cách vừa "hồn nhiên" vừa đầy chủ ý. Điều này được bộc lộ rõ hơn trong truyện kể về "Viên ngọc rết và chiếc khăn đội đầu", khi các tác giả dân gian sử dụng yếu tố thần kì để miêu tả, xây dựng hình ảnh một thủ lĩnh Hoàng Hoa Thám bất tử.

Theo truyền tụng của dân gian, Đề Thám có thể đi mây về gió, vượt qua tất cả các cuộc chiến hiểm nguy và trở thành bất tử bởi ông được "trời ban ngọc rết". Câu chuyện này được truyền miệng trong các hạ cấp của Đề Thám. Chuyện kể rằng: một lần hành quân trong rừng rậm, Hoàng Hoa Thám đã phát hiện một quái vật khổng lồ bò cạnh những gốc cây cổ thụ. Rượt đuổi theo dấu vết, Đề Thám phát hiện đó không phải là trăn mắc võng mà là một con rết khổng lồ. Biết đây là điềm lành có thể tận dụng nên Đề Thám quyết đuổi theo con quái vật ấy đến tận cuối rừng. Khi cách con rết chỉ một đoạn ngắn cũng là lúc trời đã tối sầm, Đề Thám rút dao găm bên hông đâm một nhát vào tử huyệt con quái vật. Con rết khổng lồ sau một hồi giãy giụa mới nhả ra một viên ngọc quý. Viên ngọc nhỏ như viên bi nhưng phát quang sáng loá cả một vùng trời. Đề Thám biết đây là bảo vật trời cho mới dùng dao rạch đùi và nhét viên ngọc rết ấy vào. Từ đó, sức mạnh trong người ông tăng lên gấp trăm vạn lần, có thể đi mây về gió, vượt qua biển người hiểm nguy như chốn không người. Minh chứng rõ ràng nhất cho sức mạnh ấy là cho dù quân Pháp có cả trăm nghìn lính trang bị hiện đại cũng không bắt được Đề Thám. Có thể nói, các tướng lĩnh và nhân dân đã có cách lý giải riêng cho sức mạnh và khả năng phi thường của thủ lĩnh Đề Thám. Họ tưởng tượng và thêm vào những tình tiết hoang đường thần bí, họ để thần linh trợ giúp cho ông.

Không bị giới hạn phạm vi, huyền thoại về Đề Thám và viên ngọc rết thần kì còn được các hạ cấp và nhân dân "lan truyền" sang phía người Pháp với dụng ý nhất định. Trong báo cáo về tình hình Yên Thế gửi Bộ trưởng Bộ Thuộc địa, viên chỉ huy tối cao các lực lượng ở Đông Dương đã viết: "Cũng cần nói thêm vai trò Đề Thám, vốn đã rất có uy thế, lại được cuờng điệu thêm qua nhũng huyền thoại. Do vậy, uy thế của y trong trí tuởng tuợng của lính bản xứ trong các đơn vị quân đội và cảnh sát của chúng ta là không thể coi thuờng" [8, tr.484]. Điều này cũng được Bouchet, viên Đại lí Pháp ở Nhã Nam ghi lại trong cuốn $O ̛ ̉$ Bắc kỳ, chi tiết về cái chết của Đề Thám: "Xác Đề Thám đã bị xẻ tù cổ đến hết xuoong sống, phải chăng để tìm hòn ngọc mà Đề Thám thuờng nói là ông ta đã láy được trong miệng của một con rết rất to? Về sau Bút-sê hỏi Lý Bắc về việc xẻ thây thì Lý Bắc thú nhận là chính hắn đã mổ và hắn không thấy ngọc nhu nguoòi ta đã nói" [4, tr.130]. Chi tiết nói về hành động xẻ thây tìm ngọc của Lý Bắc phần nào cho thấy, rõ ràng, câu chuyện kì bí của dân gian đã phát huy tác dụng trong việc cường điệu hóa sức mạnh của Đề Thám, biến vị thủ lĩnh trở thành người có tài phép, có sức mạnh siêu nhiên.

Bên cạnh đó, việc miêu tả sự phù trợ của vật thiêng, phép lạ đối với người anh hùng của dân gian còn biểu hiện thông điệp: trong hình hài cá nhân người thủ lĩnh đã mang chứa cả sức mạnh cộng đồng. Và để truyền tải thông điệp đó, dân gian đã vay mượn lối cường điệu hóa của thần thoại, hình ảnh Hùm thiêng Yên Thế được đẩy lên cao và xa vượt qua tầm vóc của con người đời thường, tiến gần đến vóc dáng một vị thần. Ở đây, "người anh hùng, nói như Hêghen, chứa trong lồng ngực của nó tất cả các thần" [dẫn theo 1, tr.117].

Miêu tả cái chết của Đề Thám, dân gian không sử dụng motif "hóa thân" mà dùng motif "cái chết thần kì”. Ở đây, tác giả dân gian gặp một mâu thuẫn trong quan niệm về người anh hùng: một mặt họ nhìn thấy tính khách quan của thời gian đời người, mặt khác họ không muốn người anh hùng phải chết. Vì thế, trước thông tin từ phía Pháp: thủ lĩnh Đề Thám bị bắt và sát hại, dân gian lại cho rằng, người bị Pháp bắt và xử tử là sư cụ chùa Lèo chứ không phải Đề Thám. Truyện này kể rằng, bọn lính tìm kiếm Đề Thám ở chùa Lèo không thấy, chúng cho đốt chùa, bắt sư cụ đi thế cho Đề Thám rồi chặt đầu sư đem bêu để ăn mừng chiến thắng $[6$, tr.158]. Có dị bản kể: trước sự truy lùng đuổi bắt ráo riết của thực dân Pháp, vì ân nghĩa với thủ lĩnh từ trước nên sư chùa Lèo giấu Đề Thám trong đường hầm bí mật để ông trốn thoát, còn sư trụ trì chùa Lèo tình nguyện giả làm Đề Thám chết thay thủ lĩnh để thủ lĩnh có cơ hội tiếp tục tổ chức chống Pháp. Khi biết cái đầu treo ở chợ Nhã Nam không phải là Đề Thám, thực dân Pháp đã cất xuống ngay. Nhiều nhân chứng có mặt ở Nhã Nam vào những ngày chúng bêu đầu Đề Thám cho biết, đó không phải đầu Đề Thám mà giống khuôn mặt nhà sư chùa Lèo vì ông này có khuôn mặt 
giống mặt Đề Thám, quân Pháp đem ra trưng để gỡ sĩ diện $[4$, tr.168].

Dân gian còn lưu truyền một nguồn tin khác, Hoàng Hoa Thám vẫn còn sống trong vùng Yên Thế, mãi sau này mới chết vì già yếu $[8$, tr.609]. Họ lưu truyền chuyện Đề Thám chết ở nhà Thống Luận - một tướng của cụ đã ra hàng về quê làm ăn. Thực ra cụ Thống Luận đã nuôi Đề Thám ở căn hầm dưới nền nhà (có dị bản là: vì sợ bị lộ nên cụ Thống Luận đưa cụ Đề Thám nằm trên thuyền thúng ở sau bếp, ngày ngày cho người mang thức ăn, đồ uống), cứ thế Hoàng Hoa Thám sống thêm hàng chục năm nữa cho đến khi trên dưới 80 hoặc 90 tuổi $[8$, tr.611]. Có truyện lại phủ nhận thông tin trên và cho rằng, khi bị quan Pháp truy sát Đề Thám cùng một số người đi theo vào nương náu nhờ nhà cụ Lí Loan, được bố trí ở nhà cầu Thày Mai ngoài rìa đồng, do bị thương nặng nên Đề Thám chết ở nhà cầu Thày Mai $[8$, tr.614].

Những câu chuyện này dẫn đến nhiều giả thuyết về vị trí ngôi mộ của Đề Thám. Thuyết thứ nhất cho rằng, sau khi chết ở nhà cầu Thày Mai, Đề Thám được chôn dưới gốc cây thông cổ thụ, cạnh một lối mòn, mai táng như thể một hành khất, không áo quan, không liệm, không nghi lễ để giữ bí mật [8, tr.614]. Phủ nhận thông tin trên, có nơi lại kể, cụ Thống Luận chôn cụ Đề Thám ở gốc cây Xanh, gần ao sát nhà mình. Cạnh đó còn có lưu truyền tin khác là khi cụ Đề Thám mất, cụ Thống Luận đã nghĩ ra cách mổ hai con ngựa lột lấy da bọc xác cụ Đề Thám, đem mai táng trong vườn nhà $[8$, tr.612].

Đối sánh với sử liệu chúng tôi nhận thấy, nhà cầm quyền Pháp và hầu hết báo chí, sử liệu Pháp ngay tại thời điểm 1913 từng tuyên bố đã bắt và chém đầu Hoàng Hoa Thám. Một số nhà nghiên cứu Việt Nam, trong đó có tác giả Khổng Đức Thiêm đã nghiêng về giả thuyết: vào đầu năm 1913, khi Hoàng Hoa Thám di chuyển tới vùng Hồ Lẩy trong khu rừng Tổ Cú, kẻ thù đã sắp đặt cho ba kẻ tay sai đến trá hàng để tiếp cận rồi bất ngờ hạ sát ông cùng hai chiến binh thân tín nhất vào sáng mồng 5 Tết năm Quý Sửu, tức ngày 10/2/1913 [8, tr.593]. Song tất cả các thuyết từ dân gian đưa ra lại phủ nhận điều đó.

Tại sao dân gian làm như vậy? Chúng tôi xin đưa ra hai lí giải: Thứ nhất, có thể thấy tính nhất quán trong cách xây dựng nhân vật anh hùng bằng cách xâu chuỗi các motif và các truyền thuyết. Từ motif "những phẩm chất đặc biệt" và thuyết Đề Thám được trời ban ngọc rết, đến cái chết mang màu sắc thần bí là một kết cấu hoàn chỉnh, hợp lí cho nhân vật Đề Thám. Trong quan niệm và niềm tin của người kể, vị thủ lĩnh có nhiều phẩm năng vượt trội, đã được Trời phù trợ thì phải bất tử, họ không chấp nhận sự thật Hùm thiêng Yên Thế lại chết dưới tay quân Pháp. Thái độ của dân gian dường như muốn chữa lại kết cục bi thảm trong thực tế. Thứ hai, dân gian muốn giữ bí mật sự thật này. Những hư cấu của dân gian có lẽ cũng hợp ý của Đề Thám, ông muốn cái chết của mình thật bí mật "chỉ trời biết, đất biết, Thám biết và qua biết" $[8, \operatorname{tr} .583]$. Uớc muốn này xuất phát từ thực tế lúc đó thực dân Pháp đã thực hiện một cách phổ biến chính sách đào mả. Đề Thám lại là người tin quỷ thần, tin chết rồi còn có hồn, còn có quyền lực về sau nên nhất định sợ sau khi chết người ta đào mả mình. Vì thế mà định chết cho kín đáo [5, tr.141] Chính nhờ những điều li kì thần bí trong các câu chuyện dân gian mà người ta dường như tin rằng, Đề Thám chưa chết và đang được thần linh che chở. Dù theo cách hiểu nào thì việc hư cấu của dân gian là hành động bảo vệ và che chở đầy thiện chí cho thủ lĩnh nghĩa quân.

Đến nay, khi sự thật về cái chết của Đề Thám đã dần đi đến sáng tỏ, nhưng mộ phần Đề Thám vẫn là ẩn số thì các nhà sử học phân tích sự kiện này vẫn phải dẫn các thuyết từ dân gian như một nguồn thông tin đối sánh. Điều này cho thấy những truyện kể dân gian về cái chết và ngôi mộ của Đề Thám đã trở thành nguồn dã sử có giá trị đối chứng không thể bỏ qua. Tác giả Tôn Quang Phiệt trong cuốn Tìm hiểu Hoàng Hoa Thám qua một số tài liệu và truyền thuyết đã viết: "Đối với cái chết của Đề Thám, xua nay có hai thuyết khác nhau: thuyết thứ nhất do chính phủ thục dân đưa ra, có báo, có sách ghi lại hẳn hoi; thuyết thứ hai do nhân dân ta truyền miệng, cũng có một sức mạnh và vẫn tồn tại cho đến ngày nay đã cách lúc bấy giờ hơn nưa thế kỉ.. Chúng ta hãy lần luợt xét các tài liệu và các truyền thuyết nói về cái chết của Hoàng Hoa Thám để cố gắng rút ra một kết luận" [6, tr.118]. Tác giả Nguyễn Văn Kiệm khi trình bày về "Những năm tháng cuối cùng của Đề Thám" có dẫn: "Xung quanh cái chết của Đề Thám, trong du luận nhân dân địa phuoong còn tồn tại nhiều nghi vấn..." [4, tr.168-169]. Tương tự, Khổng Đức 
Thiêm trong "Chương thứ chín: Những trang cuối về người anh hùng (1910-1913)" cũng dẫn và phân tích song song các nguồn sử liệu Pháp - Việt - truyện dân gian - tác phẩm văn chương viết về sự kiện này. Ông đã dẫn: "Ngày 11-2-1913, trên tờ L'Avenir du Tonkin đã có tin sốt dẻo "Đề Thám chết rồi chăng?.."", "Ngày 152-1913, cuộc khẩu cung của Trần Đắc Kỉ (Tsan Tac Ky) được tiến hành tại Hà Nội. Chưởng lí tại Tòa Thuợng thẩm Đông Duong là G. Michen chủ tọa", "nhiều tạp chí xuất bản tại Pháp và Việt Nam cũng có đăng tin này vì đối với Pháp, ở Việt Nam lúc bấy giờ Đề Thám là vật cản lón cho công cuộc bình định của họ", "Trong 'Bóng ngườ Yên Thế được viết tù̀ năm 1935, Việt Sinh cho biết ông Giáp Văn Phúc nói rằng, hằng năm dân làng vẫn làm giỗ vào ngày mồng 8 tháng Giêng. Dân làng Lèo thì khăng định, cái đầu kia là của ông sur trụ trì ở chùa làng mình, vì su ông có dung mạo khá giống Hoàng Hoa Thám..." [8, tr.593-604]. Không chỉ có sử liệu mà trong cả văn chương, một số nhà văn đã khai thác và sử dụng những hư cấu dân gian về cái chết của Đề Thám như Phan Bội Châu, Ngô Tất Tố và L.T.S, Việt Sinh... để thể hiện ý đồ nghệ thuật. Có thể nói, đây là một cách nuôi dưỡng truyện kể dân gian về Đề Thám hữu hiệu, để nó được hồi sinh trong đời sống cộng đồng sau này.

Ở phương diện thứ hai của hình thức các truyện kể dân gian về Đề Thám (sử dụng các chi tiết mang tính hiện thực theo lối kể của giai thoại), chúng tôi chú ý đến một khía cạnh bị/phải "bỏ qua" trong sử liệu do yêu cầu của việc ghi chép sử, nhưng lại được dân gian khai thác và thêu dệt khá nhiều, đó là mối tình của Đề Thám với cô $\mathrm{Ba}$ Cẩn - tức bà Đặng Thị Nhu, sau này là vợ $\mathrm{Ba}$ của ông. Theo những ghi chép lịch sử, bà $\mathrm{Ba}$ Cẩn là người tham mưu tin cậy, cánh tay đắc lực cho Hoàng Hoa Thám: "Các muu kế nhu cho người trá hàng, hay bắt các nguời Pháp để đòi chuộc tiền; quyết định hòa hoãn lâu dài để chò̀ thời cơ lập quán nuớc và đi thăm dò trong dân trong nuớc để chiêu mộ nguời tài, phối hợp hành động... đều có phần đóng góp quan trọng của bà $B a^{\prime \prime}[8$, tr.566-567]. Tác giả dân gian kể rằng bà có phép bấm độn, tiên đoán trước sự việc, lại được bà Ba Vàng (vợ Cai Vàng) truyền cho đường cung kiếm ${ }^{3}$.

\footnotetext{
${ }^{3}$ Truyện kể rằng: "Tù nhỏ bà Ba được ngườ cha với vốn kiến thức uyên thâm đã truyền dạy cho bà nhũng thủ thuật hiếm có để làm nhũng việc lớn trong thiên hạ. Nhu phép tính trong Thái Át thần kinh (phép tính này trong lịch sủ Việt Nam mới chỉ có Trạng Trình Nguyễn
}

Mối tình giữa Cô Cẩn và Đề Thám được dân gian hình dung rằng: bà $\mathrm{Ba}$ là người nhan sắc lại tài năng nên gia đình bà bị một tên quan nhà giàu trong vùng ép gả cưới. Căm hận bọn quan lại bất nhân, lại nghe tiếng lành của Đề Thám nên bà đã lặn lội "cọc đi tìm trâu" ngược dòng sông Thương lên Bố Hạ - Yên Thế để gặp được người thủ lĩnh trong mộng và cũng là cách công khai chống đối lại cường quyền. Sau ba ngày đàm đạo chính sự tại đền Bến Nhãn (đền thờ Trần Hưng Đạo), Đề Thám thấy cô gái họ Đặng là người am hiểu nên đã nhanh chóng kết duyên chồng vợ. Từ đó, bà $\mathrm{Ba}$ Cẩn vừa là vợ vừa là một quân sư cho Đề Thám.

Nhưng lại có chuyện khác, kể rằng: Đề Thám tới làng Vạn Vân, trên đường đi gặp một cô gái xinh đẹp, khỏe mạnh đó là Đặng Thị Nhu. Cha cô có người con nuôi là Thống Luận là một vị tướng của Đề Thám. Thấy Đề Thám và cô Nhu tâm đồng ý hợp, với sự cho phép của cha già, chẳng bao lâu cô Nhu trở thành vợ ba của Hoàng Hoa Thám, khi thành hôn Đặng Thị Nhu có tên mới là "Bà Ba Cẩn"4.

Hoặc là: Khi Đề Thám đi lánh nạn tại một ngôi làng nhỏ ông gặp bà Đặng Thị Nhu. Đề Thám nói dối là mình là dân buôn bị cướp hết tiền. Thương cảm, bà Nhu mới đưa Đề Thám về gặp cha. Từ đó, gia đình bà Nhu trở thành cơ sở bí mật của nghĩa quân Yên Thế. Rồi tâm đầu ý hợp nên chỉ một thời gian ngắn, Đề Thám cưới bà Nhu làm vợ thứ ba và đưa về đồn Phồn Xương để cùng bàn soạn hoạt động chống thực dân Pháp 5 .

Có thể nhận thấy, trí tưởng tượng dân gian về mối tình của Đề Thám và cô Cẩn khá phong phú. Ở góc độ khác - một thủ lĩnh nghĩa quân - Đề Thám được hình dung là một con người bình thường. Đề Thám cũng có những rung động trước người đẹp, có những khát khao tình yêu. Tuy nhiên, ở góc riêng tư nhất ây, nhân vật của trí tưởng tượng dân gian vẫn không vượt thoát

Bỉnh Khiêm lĩnh hội được) bà Nhu cũng thuộc làu trong lòng bàn tay. Ngoài ra, bà Nhu còn thông thuộc kỳ môn độn giáp, có thể tiên đoán trước được nhiều sư việc. Vì vầy, nhiều trận đánh với sư cố vấn của bà, Đề Thám đã nhanh chóng giành chiến thắng"; Có dị bản kể: "bà Ba Vàng thực ra không chịu duõng nhàn, biết vận nước còn tao loạn, cần người giúp dân nên đã đi tìm người để truyền lại gươm vàng. Về sau bà gặp được Đặng Thị Nhu để bày vẽ đường cung kiếm, khiến cho bà Nho trở thành bà Ba Đề Thám sau này" [11, tr.84].

${ }^{4}$ Dẫn theo http://www.yenthe.vn/node/3367.

${ }^{5}$ Dẫn theo http://kienthuc.net.vn/tham-cung/huyen-thoai-ba-ba-cuahum-thieng-yen-the-225341.html 
khỏi bổn phận và bộc lộ phẩm chất của người đứng đầu nghĩa quân. Tình yêu của Đề Thám dành cho cô Cẩn không đơn thuần chỉ vì nhan sắc mà còn vì tài chí, khí phách của người con gái này. Con mắt xanh tinh tường của Đề Thám đã nhìn ra năng lực vượt trội của cô Cẩn chỉ qua một lần tình cờ gặp, đó là những phẩm chất cần có của "nhan sắc tri kỷ" và những "tài phép" có thể trợ giúp cho cuộc khởi nghĩa. Cô Cẩn đã không để ông phải thất vọng về sự chọn lựa. Minh chứng là sau khi nên duyên vợ chồng, hai người "tâm đầu ý hợp", luôn sát bên nhau trong những hoạt động kháng chiến. Có thể nói, những hư cấu của dân gian về mối tình Đề Thám và cô Cẩn không làm giảm đi vầng hào quang của người anh hùng trong lòng dân, trái lại đã tăng thêm một cái nhìn thiện cảm với ông ở góc độ con người đời thường. Việc dân gian miêu tả tỉ mỉ và phong phú câu chuyện tình yêu giữa Đề Thám và Cô Cẩn cho thấy họ đặc biệt "để ý" đến mối quan hệ này. Góc riêng tư mà sử liệu buộc phải bỏ qua này lại là nơi trí tưởng tượng dân gian được tự do tạo tác. Và cũng nhờ đó, các nhà văn sau này có nguồn mạch phong phú để tiếp tục khai thác. Câu chuyện tình yêu của cô Cẩn và Đề Thám được tái hiện sinh động trong truyện Cầu Vồng Yên Thế (Trần Trung Viên), tiểu thuyết Nguời trăm năm cũ (Hoàng Khởi Phong)... là những ví dụ.

Như vậy, phương thức kết hợp các motif theo hướng thiêng hóa và việc sử dụng chi tiết hiện thực khi xây dựng nhân vật lịch sử cho thấy xu hướng tạo dựng một người anh hùng trong các sáng tác của dân gian. Bằng cách này, họ đã tạo nên một biểu tượng Hoàng Hoa Thám đặc biệt trong các chuyện kể. Hình tượng Đề Thám vừa mang tính hiện thực vừa mang tính kì vĩ, với dáng vóc của nhân vật anh hùng truyền thuyết, chứa đựng trong đó những thông điệp có sức lan tỏa và đối kháng mạnh mẽ với diễn ngôn áp đặt của thực dân về vị thủ lĩnh. Phiên bản Đề Thám nhìn theo hướng này đã trở thành điểm tựa tinh thần quan trọng mà cộng đồng cần dựa vào trong giai đoạn mà "niềm tin" và những biến cố lịch sử xã hội đang biến đổi theo sự vận động của thời gian.

Tựu trung lại, ở truyện kể dân gian về Hoàng Hoa Thám, vai trò của tác giả dân gian chủ yếu là kể và tả, sự cường điệu kết hợp với tưởng tượng và sử dụng yếu tố thần kì để lí giải hiện thực và tăng sức hấp dẫn cho câu chuyện. Dễ dàng nhận thấy, trong tiềm thức người dân, Hoàng Hoa Thám là một vị thủ lĩnh tài năng, khí phách và phẩm chất hơn người. Cùng với những chiến công hiển hách và sự hy sinh của ông, những phẩm chất ấy đã làm nên sức sống bền bỉ của hình tượng người anh hùng nông dân Đề Thám trong đời sống nhân dân.

\section{TÀI LIÊUU THAM KHẢO}

1. Trần Thị An (2014), Đặc trung thể loại và việc văn bản hóa truyền thuyết dân gian, Nxb Khoa học Xã hội, Hà Nội;

2. Phan Bội Châu (1917), Chân tuoóng quân (Chương Thâu dịch, Trần Hải Yến giới thiệu và tuyển chọn trong Phan Bội Châu tác phẩm chọn lọc), $\mathrm{Nxb}$ Giáo dục Việt Nam ;

3. Lê Bá Hán, Trần Đình Sử, Nguyễn Khắc Phi (đồng chủ biên, in lần thứ 3,2004 ), Tù điển thuật ngũ văn học, Nxb Giáo dục, Hà Nội ;

4. Nguyễn Văn Kiệm (1985), Phong trào nông dân Yên Thế chống thực dân Pháp xâm lược, Nxb Giáo dục, Hà Nội ;

5. Đinh Xuân Lâm, Nguyễn Văn Sự, Trần Hồng Việt (1958), Hoàng Hoa Thám và phong trào nông dân Yên Thế, Nxb Văn hóa, Hà Nội ;

6. Tôn Quang Phiệt (1984), Tìm hiểu vể Hoàng Hoa Thám (qua một số tài liệu và truyền thuyết), Sở Văn hóa Thông tin Hà Bắc;

7. Nguyễn Thị Tâm (2004), Hình tương Hoàng Hoa Thám và nghĩa quân trong văn học dân gian và lễ hội tuởng niệm ở vùng Yên Thế - Bắc Giang, Khóa luận tốt nghiệp, Trường Đại học Sư phạm Hà Nội;

8. Khổng Đức Thiêm (biên soạn, 2014), Hoàng Hoa Thám (1836-1913), Nxb Tri thức, Hà Nội;

9. Ngô Tất Tố - L.T.S (1935), Lịch sư quân Đề-Thám Yên-Thế (truyện lịch sử), Nhà in Nhật Nam, Hà Nội;

10. Vũ Anh Tuấn (2012), Giáo trình văn học dân gian, Nxb Giáo dục Việt Nam, Hà Nội;

11. Anh Vũ, Nguyễn Xuân Cần (1993), Một vùng Yên Thế, Sở Văn hoá Thông tin và Thể thao Hà Bắc;

12. Hải Vy (sưu tầm, biên soạn, có minh họa, 2010), Kể chuyện Hoàng Hoa Thám, Nxb Lao động, Hà Nội. 


\section{Hoang Hoa Tham and folk tales}

Trieu Thi Linh

\section{Article info}

Recieved:

06/03/2018

Accepted:

12/6/2018

Keywords:

Hoang Hoa Tham,

folk tales.

\begin{abstract}
The problem of developing curriculum for nursery, primary and secondary teachers is not new in pedagogical schools. However, the teacher training system still remain a lots of problems, especially the post-training professional competence is not clear. This article helps to clarify the issues of teaching competence, the orientation of program organization and training activities focusing on competence.
\end{abstract}

